Hidekazu Nishigori • Shirou Yamada • Tomoko Kohama Toshihiro Utsugi • Hiroyuki Shimizu • Toshiyuki Takeuchi Jun Takeda

\title{
Mutations in the hepatocyte nuclear factor-1 $\alpha$ gene (MODY3) are not a major cause of early-onset non-insulin-dependent (type 2) diabetes mellitus in Japanese
}

Received: September 17, 1997 / Accepted: November 19, 1997

\begin{abstract}
Maturity-onset diabetes of the young (MODY3), a monogenic subtype of non-insulin-dependent diabetes mellitus (NIDDM) with an early age of onset, is characterized by a primary defect in insulin secretion. Recently, it has been shown that mutations of the gene encoding the transcription factor hepatocyte nuclear factor-1 $\alpha$ (HNF-1 $\alpha$ ) cause MODY3. Since NIDDM in Japanese is characterized by insulin secretory defects due to primary $\beta$-cell dysfunction, we screened 60 Japanese nonobese subjects with earlyonset NIDDM for mutations in this gene, 45 of whom had a first-degree relative with NIDDM. Direct sequencing of the ten exons and flanking introns of the gene in these subjects identified eight nucleotide substitutions including two amino acid changes, Ile-27-Leu and Ser-487-Asn, the frequencies of which were not significantly different in subjects with early-onset NIDDM and nondiabetic subjects. These results suggest that mutations in the $H N F-1 \alpha$ gene are not a major cause of early-onset NIDDM in Japanese.
\end{abstract}

H. Nishigori $\cdot$ S. Yamada $\cdot$ J. Takeda $(\bowtie)$

Department of Cell Biology, Institute for Molecular and Cellular Regulation, Gunma University, 3-39-15 Showa-machi, Maebashi, Gunma 371-8512, Japan

Tel. +81-272-20-8830; Fax +81-272-20-8889

e-mail: jtakeda@akagi.sb.gunma-u.ac.jp,

H. Nishigori · T. Takeuchi

Department of Molecular Medicine, Institute for Molecular and

Cellular Regulation, Gunma University

S. Yamada

Department of Pediatrics, Gunma University School of Medicine, Maebashi, Gunma, Japan

T. Kohama

Department of Laboratory Medicine, Gunma University School of Medicine, Maebashi, Gunma, Japan

H. Shimizu

First Department of Internal Medicine, Gunma University School of Medicine, Maebashi, Gunma, Japan

T. Utsugi

Second Department of Internal Medicine, Gunma University School of Medicine, Maebashi, Gunma, Japan
Key words Maturity-onset diabetes of the young (MODY) - Mutation screening · Direct sequencing

\section{Introduction}

Non-insulin-dependent (type 2) diabetes mellitus (NIDDM) is a heterogeneous disorder of glucose homeostasis characterized by defects in the secretion and action of insulin, and is a major public health problem affecting approximately $4 \%$ of the population in Japan. Genetic factors contribute to its development, in concert with environmental factors. Maturity-onset diabetes of the young (MODY) is a monogenic subtype of NIDDM characterized by an early age of onset, often in childhood or adolescence, and inherited as an autosomal dominant trait (Fajans 1990).

Recent genetic studies have identified three distinct loci associated with the development of MODY (Bell et al. 1991; Vionnet et al. 1992; Vaxillaire et al. 1995). Clinical studies of MODY3 show that insulin secretory defects are the primary cause of the hyperglycemia in patients (Vaxillaire et al. 1995; Byrne et al. 1996). Recently, Yamagata et al. (1996) have shown that mutations in the gene encoding hepatocyte nuclear factor-1 $\alpha$ (HNF-1 $\alpha$ ) (TCF1) are the defects which cause MODY3. HNF-1 $\alpha$ is a homeodomain-containing transcription factor first identified in liver and also expressed in some other tissues and in an insulin-producing cell line (Frain et al. 1989; Tronche and Yaniv 1992; Emens et al. 1992). However, the molecular mechanism by which mutations in this gene elicit the symptoms of NIDDM is still unknown.

Recent studies of subjects with MODY in UK, France, Denmark, USA, and Japan indicate that mutations in the $H N F-1 \alpha$ gene are commonly the cause of this autosomal dominant form of familial diabetes (Frayling et al. 1997; Vaxillaire et al. 1997; Hansen et al. 1997; Yamagata et al. 1996; Iwasaki et al. 1997). Since mutations in this gene are not a major cause of late-onset NIDDM (Yamada et al. 1997a; Iwasaki et al. 1997; Urhammer et al. 1997; 
Glucksmann et al. 1997), they appear to be most strongly associated with early-onset diabetes. Because the clinical profiles of MODY3, including the age at onset, penetrance of phenotype, and the severity of diabetes and its complications, are heterogeneous, regardless of the location of the mutations on the gene (Vaxillaire et al. 1997), it is important for diagnosis to know the prevalence of mutations of this gene in other forms of early-onset diabetes. Genetic studies of Western Finnish subjects suggest that NIDDM associated with low insulin secretion is associated with the MODY3 locus in this population (Mahtani et al. 1996). Since NIDDM in Japanese is characterized by primary defects of insulin secretion in pancreatic $\beta$-cells, rather than insulin resistance with a primary defect in the insulin action pathway (Kosaka et al. 1977), it is interesting to know the prevalence of $H N F-1 \alpha$ mutations in the more common types of early-onset NIDDM in Japanese. In the present study, we screened 60 Japanese subjects with early-onset NIDDM, who were randomly selected from an epidemiological survey, for mutations in the $H N F-1 \alpha$ gene.

\section{Subjects and methods}

\section{Subjects}

Gunma Prefecture, $100 \mathrm{~km}$ north of Tokyo, has a population of two million (1995). An epidemiological survey of diabetes in youth was conducted in the prefecture in 1994 (Ishiyama et al. 1995). According to the survey, the prevalence of diabetes in youth was $0.5 \%$ (48) in those 10-19 years of age, $1.0 \%$ (99) in those 20-29 years, and 2.6\% (245) in those 30-35 years in 9522 diabetic patients selected from 22 clinics in Gunma. Sixty-four of the young patients had insulin-dependent diabetes mellitus (IDDM) and were not included in this study. IDDM in these patients was diagnosed on the basis of markedly elevated blood glucose levels, sudden onset of symptoms, and dependency on insulin treatment to sustain life. One hundred and twenty-four nonobese patients (body mass index $<25$ ) were diagnosed with NIDDM before the age of 30 years; NIDDM was diagnosed by a $75-\mathrm{g}$ or $1.75-\mathrm{g}$ per $\mathrm{kg}$ body weight oral glucose tolerance test. Of these patients, 48 were available to be subjects in this study (body mass index 21.7 \pm 3.1 ), and they represented approximately $5 \%$ of the entire population of early-onset ( $<30$ years) NIDDM patients with no obesity in the prefecture (48/124 [fraction of subjects with early-onset - $<30$ years - NIDDM involved in this study] $\times 9522 / 80,000$ [9522 diabetic subjects were selected for the survey from a diabetic population of 80,000 in Gunma Prefecture] $\times 100)$.

These 48 subjects and an additional 12 subjects who presented with NIDDM between 31 and 35 years of age and had a first-degree relative with NIDDM were examined (Table 1). Five of them had at least three generations of direct relatives with NIDDM, exhibiting an autosomal dominant-like mode of inheritance of diabetes. Although all the subjects examined were initially treated only by diet,
Table 1 Study group of subjects with early-onset non-insulindependent diabetes mellitus (NIDDM)

\begin{tabular}{llcllr}
\hline \multirow{2}{*}{$\begin{array}{l}\text { Age at } \\
\text { diagnosis }\end{array}$} & $\begin{array}{l}\text { Number of } \\
\text { subjects }\end{array}$ & $\begin{array}{l}\text { Family } \\
\text { history }\end{array}$ & & \multicolumn{3}{c}{$\begin{array}{l}\text { Current } \\
\text { therapy }\end{array}$} \\
\cline { 3 - 6 } & & & Insulin & $\begin{array}{l}\text { Oral } \\
\text { hypoglyce- } \\
\text { mic agent }\end{array}$ & Diet \\
\hline$\sim 10$ & 2 & $2(1)$ & 1 & 0 & 1 \\
$11-20$ & 12 & $9(8)$ & 6 & 1 & 5 \\
$21-30$ & 34 & $28(24)$ & 9 & 6 & 19 \\
$31-35$ & 12 & $12(12)$ & 5 & 3 & 4 \\
Total & 60 & $51(45)$ & 21 & 10 & 29 \\
\hline
\end{tabular}

Distribution of onset age of NIDDM, number of subjects examined, number of subjects with a family history of diabetes, and the current therapy are shown. The number of subjects with a first-degree relative with NIDDM is indicated in parentheses. Subjects with an onset age of less than 30 years were randomly selected from the early-onset NIDDM survey program. Subjects with an onset age between 31 and 35 years also were included in the study, if they had a first-degree relative with NIDDM. Male/female $=29 / 31$.

31 of them developed diabetes; of these, 21 are currently being treated with insulin and 10 with oral hypoglycemic agents. None of them had autoimmune antibodies, such as anti-GAD antibodies.

\section{Screening of the $H N F-1 \alpha$ gene}

The ten exons and flanking introns of the $H N F-1 \alpha$ gene (TCF1) (Kaisaki et al.1997) were screened for mutations by direct sequencing of the polymerase chain reaction (PCR) products using specific primers and the ABI PRISM Dye Terminator Cycle Sequencing FS Ready Reaction Kit [Perkin-Elmer (Applied Biosystems), Foster City, CA, USA]. The sequencing reactions were analyzed by Applied Biosystems DNA sequencers.

\section{Results}

Direct sequencing of the $H N F-1 \alpha$ gene in these subjects revealed eight nucleotide substitutions, of which two led to amino acid replacements. These changes were Ile (ATC)27-Leu (CTC) and Ser (AGC)-487-Asn (AAC) in exons 1 and 7 , respectively. The frequencies of these two mutations were not significantly different in early-onset NIDDM and nondiabetic Japanese subjects [27-Leu: 0.44 (NIDDM) vs 0.42 (normal); 487-Asn: 0.50 (NIDDM) vs 0.46 (normal); 100 nondiabetic subjects (200 chromosomes) were genotyped]. The other six nucleotide substitutions were two silent polymorphisms of Leu-17 (CTC-CTG) and Leu-459 (CTG-TTG), and four polymorphisms of nt-42 (G/A), nt-23 (C/T), nt-51 (T/A), and nt-7 (G/A) in introns 1, 2, 2, and 7 , respectively, which have been described previously at similar frequencies in white subjects (Yamagata et al. 1996). 


\section{Discussion}

Recent studies have shown that mutations in the $H N F-1 \alpha$ gene are a common cause of MODY in European Caucasians and, to a lesser extent, in Japanese; $25 \%-50 \%$ in France, $73 \%(11 / 15)$ in UK, 56\% (5/9) in Denmark, and $15 \%$ (6/41) in Japanese (Vaxillaire et al. 1997; Frayling et al. 1997; Hansen et al. 1997; Iwasaki et al. 1997). Mutations at a frequency of $9 / 25(36 \%)$ were reported in German subjects who were diagnosed with NIDDM before 35 years of age and had a first-degree relative with NIDDM, regardless of the relative's age at onset; this suggests that many of the familial early-onset NIDDM cases in Germany could be a monogenic form (Kaisaki et al. 1997). Thus, it is important to ascertain whether these findings pertain to other forms of early-onset diabetes.

Recently, we have shown that mutations in the $H N F-1 \alpha$ gene are also an important cause of a subtype of insulindependent diabetes mellitus (IDDM) in Japanese (Yamada et al. 1997b). The present study group consisted of 60 Japanese subjects with NIDDM of onset before 35 years of age, 51 of whom had a family history of diabetes (45 had a first-degree relative with NIDDM). It has been estimated that $13 \%$ of Caucasian families studied in France have a form of MODY (Froguel et al. 1991). However, since only a small fraction of the subjects studied in the current report showed an autosomal dominant-like mode of inheritance of the diabetes, most of the early-onset NIDDM in Gunma Prefecture should be a non-MODY type of familial diabetes or a low-penetration type of MODY. The subjects were screened for mutations in the $H N F-1 \alpha$ gene, and none of the mutations that might lead to the development of NIDDM were found, although only the coding region and flanking introns of the $H N F-1 \alpha$ gene were examined. These results suggest that mutations in the $H N F$ $1 \alpha$ gene are not a major cause of early-onset NIDDM in Japanese.

Acknowledgments This work was supported by the Japanese Ministry of Science, Education, and Culture, the Uehara Memorial Foundation, The Naito Foundation, and Juvenile Diabetes Foundation International.

\section{References}

Bell GI, Xiang K-S, Newman MV, Wu S-H, Wright LG, Fajans SS, Spielman RS, Cox NJ (1991) Gene for non-insulin-dependent diabetes mellitus (maturity-onset diabetes of the young subtype) is linked to DNA polymorphism on human chromosome 20q. Proc Natl Acad Sci USA 88: 1484-1488

Byrne MM, Sturis J, Menzel S, Yamagata K, Fajans SS, Dronsfield MJ, Bain SC, Hattersley AT, Velho G, Froguel P, Bell GI, Polonsky KS (1996) Altered insulin secretory responses to glucose in diabetic and nondiabetic subjects with mutations in the diabetes susceptibility gene MODY3 on chromosome 12. Diabetes 45: 1503-1510

Emens LA, Landers DW, Moss LG (1992) Hepatocyte nuclear factor $1 \mathrm{a}$ is expressed in a hamster insulinoma line and transactivates the rat insulin I gene. Proc Natl Acad Sci USA 89: 7300-7304

Fajans SS (1990) Scope and heterogeneous nature of MODY. Diabetes Care 13: 49-64
Frain M, Swart G, Monaci P, Nicosia A, Stampfli S, Frank R, Cortese R (1989) The liver-specific transcription factor LF-B1 contains a highly diverged homeobox DNA binding domain. Cell 59: 145-157

Frayling TM, Bulman MP, Ellard S, Appleton M, Dronsfield MJ, Mackie ASR, Baird JD, Kaisaki PJ, Yamagata K, Bell GI, Bain SC, Hattersley AT (1997) Mutations in the hepatocyte nuclear factor-1a gene are a common cause of maturity-onset diabetes of the young in the UK. Diabetes 46: 720-725

Froguel P, Velho G, Cohen D, Passa P (1991) Strategies for the collection sibling-pair data for genetic studies in type 2 (non insulindependent) diabetes mellitus. Diabetologia 34: 685

Glucksmann MA, Lehto M, Tayber O, Scotti S, Berkemeier L, Pulido JC, Wu Y, Nir W-J, Fang L, Markel P, Munnelly KD, Goranson J, Orho M, Young BM, Whitacre JL, McMenimen C, Wantman M, Tuomi T, Warram J, Forsblom CM, Carlsson M, Rosenzweig J, Kennedy G, Duyc GM, Krolewski AS, Groop LC, Thomas JD (1997) Novel mutations and a mutational hotspot in the MODY3 gene. Diabetes 46: 1081-1086

Hansen T, Eiberg H, Rouard M, Vaxxilaire M, Moller AM, Rasmussen SK, Fridberg M, Urhammer SA, Holst JJ, Almind K, Echwald SM, Hassen L, Bell GI, Pedersen O (1997) Novel MODY3 mutations in the hepatocyte nuclear factor- $1 \alpha$ gene: Evidence for a hyperexcitability of pancreatic $\beta$-cells to intravenous secretagogues in a glucose-tolerant carrier of a P447L mutation. Diabetes 46: 726-730

Ishiyama N, Kohama T, Kobayashi I, Nagashima K, Mori M, Kawazu S (1995) Epidemiological survey of young diabetic patients in Gunma Prefecture (in Japanese). Kitakanto Med J 45: 557-561

Iwasaki N, Oda N, Ogata M, Hara M, Hinokio Y, Oda Y, Yamagata K, Kanematsu S, Ohgawara H, Omori Y, Bell GI (1997) Mutations in the hepatocyte nuclear factor-1 $\alpha / M O D Y 3$ gene in Japanese subjects with early-onset and late-onset NIDDM. Diabetes 46: 1504-1508

Kaisaki PJ, Menzel S, Lindner T, Oda N, Rjasanowski I, Sahm J, Meincke G, Schulze J, Schmechel H, Petzold C, Ledermann HM, Sachse G, Boriraj VV, Menzel R, Kerner W, Turner RC, Yamagata K, Bell GI (1997) Mutations in the hepatocyte nuclear factor-1 $\alpha$ gene in MODY and early-onset NIDDM: Evidence for a mutational hotspot in exon 4. Diabetes 46: 528-535

Kosaka K, Hagure R, Kuzuya T (1977) Insulin responses in equivocal and definite diabetes, with special reference to subjects who had mild glucose intolerance but later developed definite diabetes. Diabetes 26: 944-952

Mahtani MM, Widen E, Lehto M, Thomas J, McCarthy M, Brayer J, Bryant B, Chan G, Daly M, Forsblom C, Kanninen T, Kirby A, Kruglyak L, Munnelly K, Parkkonen M, Reev-Daly MP, Weaver A, Brettin T, Duyk G, Lander ES, Groop LC (1996) Mapping of a gene for type 2 diabetes mellitus associated with an insulin secretion defect by a genome scan in Finnish families. Nat Genet 14: 90-94

Tronche F, Yaniv M (1992) HNF1, a homeoprotein member of the hepatic transcription regulatory network. Bioessays 14:579-589

Urhammer SA, Rasmussen SK, Kaisaki PJ, Oda N, Yamagata K, Moller AM, Fridberg M, Hansen L, Hansen T, Bell GI, Pedersen O (1997) Genetic variation in the hepatocyte nuclear factor-1 $\alpha$ gene in Danish Caucasians with late-onset NIDDM. Diabetologia 40: 473475

Vaxillaire M, Boccio V, Philippi A, Vigouroux C, Terwilliger J, Passa P, Beckmann JS, Velho G, Lathrop GM, Froguel P (1995) A gene for maturity onset diabetes of the young (MODY) maps to chromosome 12q. Nat Genet 9: 418-423

Vaxillaire M, Rouard M, Yamagata K, Oda N, Kaisaki PJ, Boriraj VV, Chevre JC, Boccio V, Cox RD, Lathrop GM, Dussoix P, Philippe J, Timsit J, Charpentier G, Velho G, Bell GI, Froguel P (1997) Identification of nine novel mutations in the hepatocyte nuclear factor 1 alpha gene associated with maturity-onset diabetes of the young (MODY3). Hum Mol Genet 6: 583-586

Vionnet N, Stoffel M, Takeda J, Yasuda K, Bell GI, Zouali H, Lesage S, Velho G, Iris F, Passa P, Froguel P, Cohen D (1992) Nonsense mutation in the glucokinase gene causes early-onset noninsulin-dependent diabetes mellitus. Nature 356: 721-722

Yamada S, Nishigori H, Onda H, Takahashi K, Kitano N, Morikawa A, Takeuchi T, Takeda J (1997a) Mutations in the hepatocyte nuclear factor-1 $\alpha$ gene (MODY3) are not a major cause of late-onset NIDDM in Japanese subjects. Diabetes 46: 1512-1513

Yamada S, Nishigori H, Onda H, Utsugi T, Yanagawa T, Maruyama T, Onigata K, Nagashima K, Nagai R, Morikawa A, Takeuchi T, 
Takeda J (1997b) Identification of mutations in the hepatocyte nuclear factor (HNF)-1 $\alpha$ gene in Japanese subjects with IDDM. Diabetes 46: 1643-1647

Yamagata K, Oda N, Kaisaki PJ, Menzel S, Furuta H, Vaxillaire M, Cox RD, Lathrop GM, Boriraj VV, Chen X, Cox NJ, Oda Y, Yano
H, LeBeau MM, Yamada S, Nishigori H, Takeda J, Chevre J-C, Fajans SS, Hattersley AT, Iwasaki N, Pedersen O, Polonsky KS, Turner RC, Froguel P, Bell GI (1996) Mutations in the hepatocyte nuclear factor-1 $\alpha$ gene in maturity-onset diabetes of the young (MODY3). Nature 384: 455-45 